\title{
A Comparative Study on the Construction of Economics Major in Local Universities Based on Text Analysis-Taking Eight Local Colleges and Universities in Shaanxi as an Example
}

\author{
Wei Zhao ${ }^{1,2}$, Ping Zhang ${ }^{3}$ \\ ${ }^{1}$ School of international business, Southwestern university of finance and economics, Chengdu, Sichuan, \\ 611130, China \\ ${ }^{2}$ ASEAN Boren College of Finance and Economics, Weinan Normal University, Weinan, Shaanxi, 714099, \\ China \\ ${ }^{3}$ ASEAN Boren College of Finance and Economics, Weinan Normal University, Weinan, Shaanxi, 714099, \\ China
}

Keywords: local colleges, Economics, Major construction.

\begin{abstract}
With the development of science and technology and the complexity of talent competition and economic globalization, the Chinese government has proposed a plan to promote the construction of world-class universities and world-class disciplines, thus put forward new requirements for the major construction reform of colleges and universities, and brought a new direction of development. This paper takes the construction of economics as an example, conducts research on local universities in Shaanxi Province with economics major, and uses text analysis methods to conduct comprehensive comparative analysis from five aspects: training objectives, quality courses, practical teaching, teaching teams and scientific research results. The corresponding countermeasures and suggestions for the construction of economics major in local colleges and universities in Shaanxi Province were put forward.
\end{abstract}

\section{Introduction}

With the development of science and technology and the complexity of talent competition and the trend of economic globalization, the Chinese government has proposed the Overall Plan for Promoting the Construction of World-Class Universities and First-Class Disciplines. As an important force in the national colleges and universities, local undergraduate colleges and universities occupy half of the number of schools and students. In the "two first-class" national strategic layout, the major construction and development of undergraduate local colleges and universities is important for the improvement of the quality of Chinese personnel training.

According to the discipline division of the Ministry of Education, economics major include theoretical economics and applied economics. The economics major belongs to the first-level discipline of theoretical economics. This means that when the economics major is established, it has a strong theoretical theory. It requires the cultivation of economics major to focus on the cultivation of theoretical quality, and also proposes the "application-oriented talent training" for economics. Small challenge. Local colleges and universities are generally born with local economic and social development and their strong demand for talents. One of their important responsibilities is to establish a local and local service. At the same time, in view of geographical location, faculty ability and school conditions, "application-oriented talent" naturally It has become the first choice for many local colleges and universities. Then, how to link the characteristics of economics with the applied talents training mode of local colleges and universities, so that local colleges and universities in the "double first-class" strategy background to develop a distinctive and differentiated development path has become a realistic problem. The solution of this problem is conducive to the improvement of the quality of personnel training in local colleges and universities, further deepening the comprehensive 
reform of economics education and teaching, and creating first-class disciplines; at the same time, it is conducive to giving play to the regional characteristics of local colleges and universities, cultivating innovative entrepreneurial talents, and serving the local economy.

\section{Research methods and research objects}

In January 2018, the Ministry of Education issued the National Standard for Undergraduate Major Teaching Quality in Ordinary Colleges and Universities, which makes clear requirements for the application of major scope, training objectives, training specifications, teaching staff, teaching conditions, and quality assurance system. In particular, the requirements for the combination of the number and structure of the faculty, the major background and level of the teacher's subject, and the conditions for the development of teachers' teaching are proposed. All colleges and universities are required to revise the talent training program according to National Standard for Undergraduate Major Teaching Quality in Ordinary Colleges and Universities to cultivate high-quality and diverse talents. Therefore, the reform of major construction in higher education institutions is also imperative. This paper will take Shaanxi local colleges and universities as an example, and adopt a comparative analysis method for local colleges with economics major. Through the manual search method, 20 local universities in Shaanxi Province (that is, the competent departments of Shaanxi Provincial People's Government) will be investigated one by one. Screening out local colleges with economics major and using text analysis to build major objectives, faculty, training programs and curriculum, quality courses, practical teaching and scientific research achievements in economics major Relevant content is extracted for comparative analysis. The 20 institutions are: Northwest University, Xi'an University of Technologies, Shaanxi University of Science and Technology, Xi'an University of Science and Technology, Northwest University of Political Science and Law, Xi'an University of Petroleum, Xi'an Engineering University, Xi'an Technological University, Xi'an University of Posts and Telecommunications, Yan'an University, Xi'an University of Finance and Economics, Xi'an University, Xi'an International Studies University, Shangluo University, Shaanxi University of Technology, Yulin University, Ankang University, Baoji University of Arts and Sciences, Xianyang Normal University. All data is sourced from the official website of each school in March 2017.

\section{A Comparative Analysis of the Construction of Economics Major in Local Universities in Shaanxi Province}

\subsection{Objectives of major construction}

Through comparative analysis, it is found that, first of all, in the training objectives, different colleges have different requirements for mastering the basic theories of economics. Weinan Normal University has reached a level of familiarity with the requirements of modern economic theory. However, both the Northwest University and the Xi'an Technological University have clearly proposed the cutting-edge theory of modern economics and the profound theoretical qualities of modern Western economics. Therefore, judging from the requirements of modern economic theory, there may be a gap between the training objectives of the economics major of Weinan Normal University and other universities in Shaanxi. Secondly, in the direction of talent cultivation, different institutions have different emphasis. The training objectives of the economics major of Weinan Normal University involve "the ability to expand penetration into economics-related fields". From this point of view, the training of economics major in Weinan Normal University is more comprehensive, and the training objectives of Xi'an Technological University are obviously focused on the direction of financial investment. Thirdly, in terms of training objectives, in view of the different orientations of universities, there is bound to be a big difference in the training objectives of economics in local universities. For example, the training objectives of Northwest University include "theoretical research talents with standardized research methods and internationalization". The training objectives of Xi'an University of Posts and Telecommunications include "encouraging 
economics graduates to further their studies at home and abroad and grow into economic research talents."Xianyang Normal University emphasizes "cultivating the talents that meet the needs of local economic development", but looking at the training objectives of the comparative colleges, the goal is to "applied talents" or "application-oriented talents", which means " Cultivating applied talents is the first choice for many economics major in colleges and universities.

\subsection{Talent development program and curriculum}

Among the seven colleges and universities, the economics major training program we have acquired includes five universities, namely Northwest University, Yan'an University, Xi'an University of Posts and Telecommunications, Xi'an Technological University and Shaanxi University of Technology. Different colleges and universities have different goals and positioning for talent training. First of all, Northwest University is a unique national key university jointly established by the Ministry of Education and the Shaanxi Provincial People's Government. It is a university listed in the "211 Project" and "Central and Western University Basic Capacity Building Project" list. It is the oldest higher education school in Northwest China.

\subsection{Practical teaching}

From the perspective of laboratory construction and practice base, the economics major of Northwest University has a doctoral degree and a master's degree in theoretical economics and a postdoctoral research station in theoretical economics. Its theoretical economics has been rated as a national first-class major. The School of Applied Economics and Management has 11 laboratories and has been awarded the title of "National Talent Training Model Innovation Experimental Zone" and "National Higher Education Specialty". Xi'an University of Finance and Economics attaches great importance to the cultivation of students' application ability. It has established 8 on-campus training centers and 29 off-campus practice bases. The School of Economics and Management of Xi'an University of Posts and Telecommunications has 8 off-campus practice bases and 2 on-campus practice bases.

\subsection{Achievements in scientific research}

From the perspective of scientific research results, as a famous university with the development of economic management disciplines in Shaanxi Province, the theoretical economics of Northwest University ranks $\mathrm{A}$ in the double first class ranking, and the economics teachers have achieved fruitful results in many economic research fields; The School of Economics of Xi'an University of Finance and Economics acquired 4 national social science fund projects during the period of 2013-2016, 1 humanities and social science research project of the Ministry of Education, and 31 provincial and ministerial level scientific research projects; School of Economics and Management of Xi'an University of Technologies focused on military management and research, as of October 2016, a total of 25 provincial and ministerial-level scientific research projects were filed, including 4 national social science fund projects, 9 national natural science fund projects, and 1 national key laboratory project; The research institutions and innovation teams established by Economics Department of Shaanxi University of Science and Technology mainly include: regional economics and technology innovation team, ecological economic research center in southwestern Shaanxi, and green recycling development technology innovation platform in southwestern Shaanxi. In the past five years, the teachers of the Department of Economics have presided over 2 national-level projects and 4 provincial-level projects; Economic Management School of Yan'an University acquired 1 Ministry of Education project, 2 provincial social science association projects, 1 provincial education science "13th Five-Year Plan" project, and 2 provincial social science projects in 2016; acquired 1 provincial social science project and 3 provincial social science association projects in 2015. Xianyang Normal University won 2 provincial social science funds in 2015, 1 major social science project in Shaanxi Province; 3 social science fund projects in Shaanxi Province approved in 2016, 2 major social science projects in Shaanxi Province; approved in 2017 A theoretical and practical research project; in 2017, four projects of education science planning in Shaanxi Province were 
approved. Table 1 is a comprehensive comparative analysis of the available information on the construction of the economics major of the seven institutions extracted from this paper.

Table 1. Comparison of available information in the construction of economics major in 7 colleges and universities in Shaanxi Province

\begin{tabular}{|c|c|c|c|c|c|}
\hline $\begin{array}{l}\text { Name of } \\
\text { colleges }\end{array}$ & $\begin{array}{l}\text { Teaching } \\
\text { staff }\end{array}$ & $\begin{array}{l}\text { Talent } \\
\text { development } \\
\text { programs and } \\
\text { curriculum } \\
\text { (credits and } \\
\text { hours) }\end{array}$ & $\begin{array}{l}\text { Courses and } \\
\text { network } \\
\text { resource } \\
\text { sharing class }\end{array}$ & $\begin{array}{l}\text { Practice Teaching } \\
\text { (2016 National } \\
\text { Undergraduate } \\
\text { Entrepreneurship } \\
\text { Projects) }\end{array}$ & $\begin{array}{l}\text { Research } \\
\text { projects } \\
(2014-20 \\
16)\end{array}$ \\
\hline $\begin{array}{l}\text { Northwest } \\
\text { University }\end{array}$ & $8 / 5 / 17$ & $172 / 2964$ & 8 & Not acquired & $\begin{array}{l}\text { Not } \\
\text { acquired }\end{array}$ \\
\hline $\begin{array}{l}\text { Xi'an } \\
\text { University of } \\
\text { Finance and } \\
\text { Economics }\end{array}$ & $6 / 26 / 9$ & Not acquired & 8 & 2/?/?/2/? & $8 / 7 / 11$ \\
\hline $\begin{array}{l}\text { Yan’an } \\
\text { University }\end{array}$ & $3 / 10 / 4$ & $137 / 2178$ & 0 & 0 & $? / 4 / 6$ \\
\hline $\begin{array}{l}\text { Xi'an } \\
\text { University of } \\
\text { Posts \& } \\
\text { Telecommunica } \\
\text { tions }\end{array}$ & $5 / 5 / 8$ & 175 & 1 & Not acquired & $3 / 4 / 2$ \\
\hline $\begin{array}{l}\text { Xi’an } \\
\text { Technological } \\
\text { University }\end{array}$ & $4 / 3 / ?$ & Not acquired & 2 & Not acquired & 25 in total \\
\hline $\begin{array}{l}\text { Shaanxi } \\
\text { University of } \\
\text { Technology }\end{array}$ & $3 / 3 / 5^{*}$ & $188.5 / 2466$ & Not acquired & Not acquired & 6 in total \\
\hline $\begin{array}{l}\text { Xianyang } \\
\text { Normal } \\
\text { University }\end{array}$ & $3 / 1 / 1$ & $168.5 / 2280$ & 1 & $\begin{array}{l}6 \text { projects were } \\
\text { approved in } 2017\end{array}$ & $3 / 5 / 5$ \\
\hline $\begin{array}{l}\text { Weinan Normal } \\
\text { University }\end{array}$ & $3 / 3 / 6^{*}$ & $159.5 / 2338$ & 3 & $1 / 1 / 3 / 1 / 2$ & 8 in total \\
\hline
\end{tabular}

Note: The data comes from the official website of each university; the inquiry time is March 2018.

\section{Suggestions on the Construction of Economics Major in Local Universities}

Through horizontal and comparative analysis with the economics major of local universities in Shaanxi Province, this paper proposes countermeasures for the construction of economics in local universities in Shaanxi Province. In the future, we should focus on adapting to regional economic requirements, cultivating talents, optimizing curriculum systems, improving teaching quality, creating high-level teaching teams and teaching platforms, and practicing the "Belt and Road" to integrate into the era of big data.

4.1 It is a prerequisite to practice the "Belt and Road Initiative" and integrate into the era of big data

As an important hub for the country to open to the west, Shaanxi universities must shoulder the mission endowed by the state, take the "Belt and Road" construction and the construction of the free trade zone as an opportunity to accelerate the cultivation of high economic majorism and meet the "Belt and Road Initiative” initiative. The demand for compound bilingual economic major. At the 
same time, with the rise of new technologies such as the mobile Internet and the Internet of Things and the launch of the basic state database of the Ministry of Education, big data has been integrated into colleges and universities, and the revolution of thinking and transformation triggered by it is exerting a strong impact on the inherent mode of teaching management in colleges and universities. Therefore, effectively using the thinking mode of the big data era to explore the development path of college major construction, effectively analyzing and predicting the direction of major construction is an inevitable trend of local colleges and universities to adapt to the new era. At the same time, having certain information technology and data processing capabilities is also a new challenge for the training of economics major in the era of big data.

\subsection{Adapting to regional economic requirements and cultivating the application of compound talents is the purpose}

Among the local colleges with economics major in Shaanxi Province, except for the specialties of Northwest University, the fundamentals of economics construction in other universities are to cultivate high-quality applied composite talents based on local, social, and national. The demand for applied talents in local economic and social development is the foundation of local undergraduate colleges. Therefore, local colleges and universities must base themselves on the reality of local economic and social development and create a direction for the construction of economics with distinctive characteristics and regional advantages. For example, the economics major of Xi'an University of Posts and Telecommunications has increased the tendency of informatization teaching and the integration of management and management, focusing on the characteristics of the postal and telecommunications industry. Yan'an University is located in Yan'an with rich coal and petroleum resources. It can be considered to reflect the direction of resource and environmental economics in the construction of economics. Weinan Normal University can consider the direction of industrial economics in the construction of economics.

\subsection{Optimizing the curriculum system and improving the quality of teaching are the key points}

If major construction is likened to a bridge, then the curriculum is the main structure of the bridge across the obstacles; and the quality of teaching is equivalent to the pier and foundation, with a high level of teaching quality, can ensure that the major construction of this bridge has a good lower structure; only the optimization of the curriculum system can ensure the smooth realization of the purpose of talent cultivation. Therefore, the two are indispensable. At the same time, the optimization of the curriculum system and the improvement of the quality of teaching are complementary and mutually symbiotic. If there is no high level of teaching quality as a guarantee for curriculum system optimization, there is no basis for this optimization; and if the quality of teaching is improved without an optimized curriculum system, this improvement is not very effective. Therefore, local colleges and universities should recognize the relationship between optimizing the curriculum system and improving the quality of teaching and their significance for major construction.

\section{Summary}

This paper focused on the analysis of the economics construction of Weinan Normal University. Through the horizontal comparison of the economics construction of local universities in Shaanxi Province, we found the problems in the construction of economics major in Weinan Normal University. Based on this, the corresponding countermeasures and suggestions for the construction of economics major in Weinan Normal University are put forward, and the future development direction of economics construction in local colleges and universities is pointed out.

\section{Acknowledgement}

This research was financially supported by the Education and Teaching Reform Research Project of Weinan Normal University (Grant NO. JG201507); Education and Teaching Reform Research 
Project of Weinan Normal University (Grant NO. JG201709).

\section{References}

[1] Wang Xuecheng. Analysis on the Matching Degree between Local College Major construction and Regional Development-Taking Shaanxi Province as an Example, Journal of Shaanxi University of Technology (Social Science Edition), 2012.04:12-17.

[2] Tian Tao. Construction of the teaching practice system of economics in local colleges and universities, Special Economic Zone. 2016.01:168-170.

[3] Guo Jianhua. The choice of major construction strategy of local colleges and universities from the perspective of applied talents training__ Taking the financial engineering major of Shaoyang College as an example, High Teaching Journal. 2016(20):72-75.

[4] Xu Liqing. Analysis of provincial level planning in the major setting of local colleges and universities, Educational Development Research. 2016(13): 85-91.

[5] Wang Xuecheng. Problems in major construction and characteristics development of local colleges and universities, Journal of Shaanxi Institute of Technology (Social Science Edition) 2012.02:73-80.

[6] Liu Gonghui. The logic and approach of "double first-class" construction in local universities, China Higher Education. 2017(18): 33-34.

[7] Xu Qiaolin, Lv Lihan. Exploration and thinking on the construction of new local undergraduate colleges, Heilongjiang Higher Education Research.2013 (11):151-154.

[8] Zhang Zizhao, Zhu Shengli. Problems and Countermeasures in the Construction of Characteristic Specialty in Local Undergraduate Colleges, Education Exploration. 2011(7): 29-31. 